\title{
Comparison of three surgical approaches for thoracolumbar junction (T12-L1) tuberculosis: a multicentre, retrospective study
}

Yanping Zeng ${ }^{1 \dagger}$, Peng Cheng ${ }^{1 \dagger}$, Jiulin Tan ${ }^{1}$, Zhilin Li², Yuan Chen ${ }^{3}$, Li Tao Li ${ }^{4}$, Yonghong Zheng ${ }^{5}$, Gaoju Wang ${ }^{6}$, Jianzhong $\mathrm{Xu}^{1}$ and Zehua Zhang ${ }^{1 *}$

\begin{abstract}
Background: The surgical approaches to thoracolumbar junction (T12-L1) tuberculosis were controversial. We aimed to compare the safety and efficacy of three different procedures through a multicentre retrospective study.

Methods: The medical records of thoracolumbar junction tuberculosis patients $(n=177)$ from January 2005 to January 2015 were collected and reviewed. Forty-five patients underwent anterior debridement and instrumented fusion (Group A), 52 underwent anterior combined with posterior debridement and instrumented fusion (Group B) and 80 underwent posterior-only debridement and instrumented fusion (Group C). Patients with neurological deficit were 10 in Group A, 23 in Group B, 36 in Group C. All patients had a standard preoperative and postoperative anti tuberculous therapy regimen. Clinical outcomes, laboratory indexes and radiological evaluation of the three groups were compared. Operations at each centre were performed by the respective senior medical teams of the six different hospitals.

Results: All three surgical approaches achieved bone fusion and pain relief. Cases with neurological deficits had different degrees of improvement after surgery. The operative time was $330.2 \pm 45.4 \mathrm{~min}, 408.0 \pm 54.3 \mathrm{~min}, 227.9 \pm$ $58.5 \mathrm{~min}$, and the blood loss was $744.0 \pm 193.8 \mathrm{ml}, 1134.6 \pm 328.2 \mathrm{ml}, 349.8 \pm 289.4 \mathrm{ml}$ in groups A, B and C respectively.

The average loss of correction was $5.5 \pm 3.7^{\circ}$ in group $A, 1.6 \pm 1.9^{\circ}$ in group $B, 1.7 \pm 2.2^{\circ}$ in group $C$, and the difference between groups except B vs $C$ were of statistically significant $(P<0.05)$.

Conclusions: For patients with thoracolumbar junction (T12-L1) tuberculosis, the posterior-only procedure is the better than the anterior-only procedure in the correction of kyphosis and maintenance of spinal stability. The posterior-only procedure is recommended because it achieves the same efficacy as combined procedure with shorter operation time, less blood loss and trauma.
\end{abstract}

Keywords: Spinal tuberculosis, Thoracolumbar junction lesion, Surgical treatment, Outcome

\footnotetext{
* Correspondence: zhangzehuatmmu@163.com

${ }^{\dagger}$ Yanping Zeng and Peng Cheng contributed equally to this work and

should both beconsidered first authors. Other authors contributed equally to

this work.

'Department of Orthopaedics, Southwest Hospital, Third Military Medical

University, Chongqing 400038, China

Full list of author information is available at the end of the article
}

(c) The Author(s). 2019 Open Access This article is distributed under the terms of the Creative Commons Attribution 4.0 International License (http://creativecommons.org/licenses/by/4.0/), which permits unrestricted use, distribution, and reproduction in any medium, provided you give appropriate credit to the original author(s) and the source, provide a link to the Creative Commons license, and indicate if changes were made. The Creative Commons Public Domain Dedication waiver (http://creativecommons.org/publicdomain/zero/1.0/) applies to the data made available in this article, unless otherwise stated. 


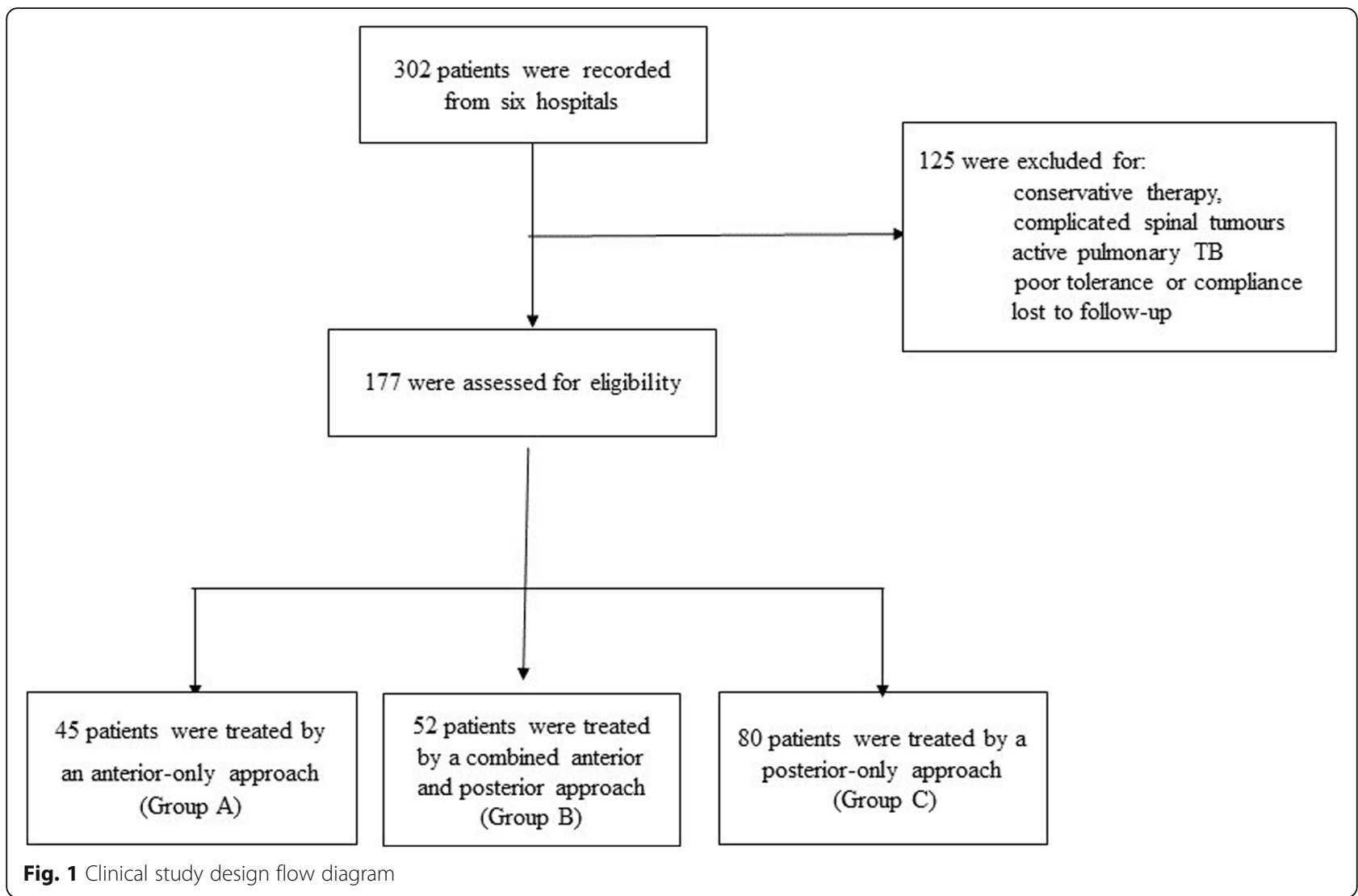

\section{Background}

Tuberculosis (TB) has an important influence on human health, especially in non-rich states [1-3]. China has the second largest TB infected population affecting an estimated 2 million people $[4,5]$. Spinal TB may lead to spinal instability, kyphotic deformities, and compression of the spinal nerve, and the thoracolumbar junction (T12-L1) is one of the main metastatic site of musculoskeletal system [6, 7]. Though most spinal TB can achieve satisfactory outcome through standard chemotherapy alone, surgical intervention is still recommended for cases with large paraspinal abscess, spinal instability, neurological injury and severe kyphosis [8, 9]. However, the surgical approaches are still controversial among spinal surgeons. Some surgeons prefer the anterior approach for its direct access to the infection foci, that is of benefit to debride and reconstruct $[10,11]$. However, persistent maintenance of spinal stability is outside the scope of such procedure [12, 13]. So, some experts recommend anterior debridement combined with posterior instrumentation which achieve excellent clinical results except for some inconvenient complications [14]. In recent years, posterior-only surgery has gained popularity because of its valid debridement, ensure decompression and kyphosis correction with limited trauma, few complications, low cost and short recovery time $[15,16]$. To our knowledge, no study was done to

Table 1 Patients' Clinical Data

\begin{tabular}{lllll}
\hline & Group A & Group B & Group C & Statistical Value \\
\hline Sex (male/female) & $21 / 24$ & $29 / 23$ & $38 / 42$ & $35.6 \pm 9.9$ \\
Average age (years) & $34.3 \pm 10.1$ & $34.4 \pm 10.4$ & $6.1 \pm 1.6$ & $\mathrm{P} 1>0.05 / \mathrm{P} 2>0.05 / \mathrm{P} 3>0.05$ \\
Preoperative VAS score & $5.7 \pm 1.6$ & $6.0 \pm 1.9$ & $227.9 \pm 58.5$ & $\mathrm{P} 1<0.05 / \mathrm{P} 2<0.05 / \mathrm{P} 3<0.05$ \\
Operation time (min) & $330.2 \pm 45.4$ & $408.0 \pm 54.3$ & $349.8 \pm 289.4$ & $\mathrm{P} 1<0.05 / \mathrm{P} 2<0.05 / \mathrm{P} 3<0.05$ \\
Blood loss (mL) & $744.0 \pm 193.8$ & $1134.6 \pm 328.2$ & $0.6 \pm 0.7$ & $\mathrm{P} 1>0.05 / \mathrm{P} 2>0.05 / \mathrm{P} 3>0.05$ \\
Final follow-up VAS score & $0.6 \pm 0.7$ & $0.5 \pm 0.6$ & $28.9 \pm 6.1$ & $\mathrm{P} 1>0.05 / \mathrm{P} 2>0.05 / \mathrm{P} 3>0.05$ \\
Follow-up duration (months) & $30.0 \pm 7.3$ & $29.7 \pm 6.6$ & &
\end{tabular}

P1:A vs B P2: A vs C P3:B vs C 
Table 2 Cobb Angle and ESR in Three Groups

\begin{tabular}{|c|c|c|c|c|c|c|}
\hline & \multirow{2}{*}{$\begin{array}{l}\text { Preoperative } \\
\text { Cobb Angle } \\
\left(^{\circ}\right)\end{array}$} & \multirow{2}{*}{$\begin{array}{l}\text { Postoperative } \\
\text { Cobb Angle }\left(^{\circ}\right)\end{array}$} & \multicolumn{2}{|l|}{ Final Follow-Up } & \multicolumn{2}{|l|}{ ESR $(\mathrm{mm} / \mathrm{h})$} \\
\hline & & & Cobb Angle $\left({ }^{\circ}\right)$ & Angle Lost $\left({ }^{\circ}\right)$ & Preoperative & 3 Months Postoperative \\
\hline A & $22.7 \pm 7.9$ & $11.2 \pm 5.4$ & $16.7 \pm 7.0$ & $5.5 \pm 3.7$ & $34.7 \pm 27.0$ & $6.1 \pm 4.7$ \\
\hline B & $18.1 \pm 6.8$ & $8.4 \pm 4.2$ & $10.1 \pm 4.4$ & $1.6 \pm 1.9$ & $38.9 \pm 30.2$ & $7.4 \pm 5.3$ \\
\hline$C$ & $20.8 \pm 8.3$ & $8.7 \pm 3.8$ & $10.3 \pm 4.0$ & $1.7 \pm 2.2$ & $36.3 \pm 25.0$ & $7.0 \pm 4.5$ \\
\hline P1 & $<0.05$ & $<0.05$ & $<0.05$ & $<0.05$ & $>0.05$ & $>0.05$ \\
\hline P2 & $>0.05$ & $<0.05$ & $<0.05$ & $<0.05$ & $>0.05$ & $>0.05$ \\
\hline P3 & $<0.05$ & $>0.05$ & $>0.05$ & $>0.05$ & $>0.05$ & $>0.05$ \\
\hline
\end{tabular}

P1:A vs $B$ P2: $A$ vs $C$ P3:B vs $C$

compare the therapeutic efficacy between anterior-only, posterior-only and anterior-posterior procedures for monosegmental spinal TB focusing on the thoracolumbar junction (T12-L1). Furthermore, there is no study comparing the three surgical methods in multiple centres and on large samples. Therefore, we conducted a multicentre retrospective research to observe the safety and efficacy of three procedures of treating thoracolumbar junction(T12-L1) TB and to provide a reference for its surgical treatment.

\section{Methods}

\section{General information}

Between January 2005 and January 2015, 302 cases with thoracolumbar junction (T12-L1) TB from six hospitals across China were hospitalized; 125 were excluded because of chemotherapy lonely, poor compliance or tolerance, complicated with active lung TB or spinal tumours, HIV co-infection and lost to follow-up (Fig. 1). The remaining 177 cases were included, comprising 88 males and 89 females with a mean age of $35.2 \pm 10.0$ years (range 14-62). Forty-five patients were treated by the anterior-only procedure (Group A), 52 by the combined anterior and posterior procedure (Group B) and 80 by the posterior-only procedure (Group C) (Table 1).

patients were diagnosed as spinal TB by clinical symptoms, signs, laboratory test, radiological examination and histopathology. Neurological function of the cases was evaluated by American Spinal Injury Association (ASIA) score. Six cases were grade A, 14 were grade C, 47 were grade $\mathrm{D}$ and 108 were grade $\mathrm{E}$. The back pain was evaluated by visual analogue scale (VAS) for all patients, and the local kyphotic angle was assessed by Cobb technique.

\section{Preoperative management}

All cases underwent chemotherapy regimens HREZ (rifampicin $450 \mathrm{mg} /$ day, isoniazid $300 \mathrm{mg} /$ day, pyrazinamide $750 \mathrm{mg} /$ day and ethambutol $750 \mathrm{mg} /$ day) for more than 2 weeks preoperatively.

\section{Operation technique}

Operations at each centre were performed by senior surgeons. All cases were treated by general endotracheal anaesthesia, then placed in the appropriate position. (1) In the anterior-only approach, thoracoabdominal procedure was adopted. After the lesion site was completely debrided, the defect area of vertebrae was inserted with a suitable cage or autologous or allograft iliac bone. Then the screw-rods were inserted in lateral anterior of the vertebrae. (2) In the anterior-posterior approach, the prone position was used initially. Dorsal midline incision was performed. The lamina and articular process were exposed, then pedicle screws were implanted in the right places. After correction of the kyphosis angle, bone grafting was performed, and the incision was closed. Then, patients were transferred to the lateral position, and a correctly placed incision was made. The thoracoabdominal approach was used to debride the lesion, decompress spinal cord and graft cage or iliac bone. (3) In the posterior-only approach, the prone position was used. Dorsal midline incision was

Table 3 ASIA Classification in Three Groups

\begin{tabular}{|c|c|c|c|c|c|c|c|c|c|c|c|c|}
\hline \multirow{2}{*}{$\begin{array}{l}\text { ASIA } \\
\text { Classification }\end{array}$} & \multicolumn{4}{|c|}{ Group A (n) } & \multicolumn{4}{|c|}{ Group B (n) } & \multicolumn{4}{|c|}{ Group C (n) } \\
\hline & $\begin{array}{l}\text { Pre- } \\
\text { operative }\end{array}$ & $\begin{array}{l}\text { Post- } \\
\text { operative }\end{array}$ & $\begin{array}{l}\text { Final } \\
\text { Follow- up }\end{array}$ & $\begin{array}{l}\text { Improve- } \\
\text { ment }\end{array}$ & $\begin{array}{l}\text { Pre- } \\
\text { operative }\end{array}$ & $\begin{array}{l}\text { Post- } \\
\text { operative }\end{array}$ & $\begin{array}{l}\text { Final } \\
\text { Follow- up }\end{array}$ & $\begin{array}{l}\text { Improve- } \\
\text { ment }\end{array}$ & $\begin{array}{l}\text { Pre- } \\
\text { operative }\end{array}$ & $\begin{array}{l}\text { Post- } \\
\text { operative }\end{array}$ & $\begin{array}{l}\text { Final } \\
\text { Follow- up }\end{array}$ & $\begin{array}{l}\text { Improve- } \\
\text { ment }\end{array}$ \\
\hline $\bar{A}$ & 0 & 0 & 0 & 0 & 3 & 0 & 0 & 3 & 3 & 0 & 0 & 3 \\
\hline B & 0 & 0 & 0 & 0 & 0 & 0 & 0 & 0 & 0 & 0 & 0 & 0 \\
\hline C & 2 & 0 & 0 & 2 & 6 & 3 & 3 & 3 & 8 & 3 & 2 & 6 \\
\hline $\mathrm{D}$ & 8 & 3 & 0 & 6 & 14 & 3 & 1 & 13 & 25 & 8 & 4 & 21 \\
\hline E & 35 & 43 & 45 & & 29 & 46 & 48 & & 44 & 69 & 74 & \\
\hline
\end{tabular}

Spinal cord function improvement rate: Group A was $80 \%$, Group B was $82.6 \%$ and Group C was $83.3 \%$ 


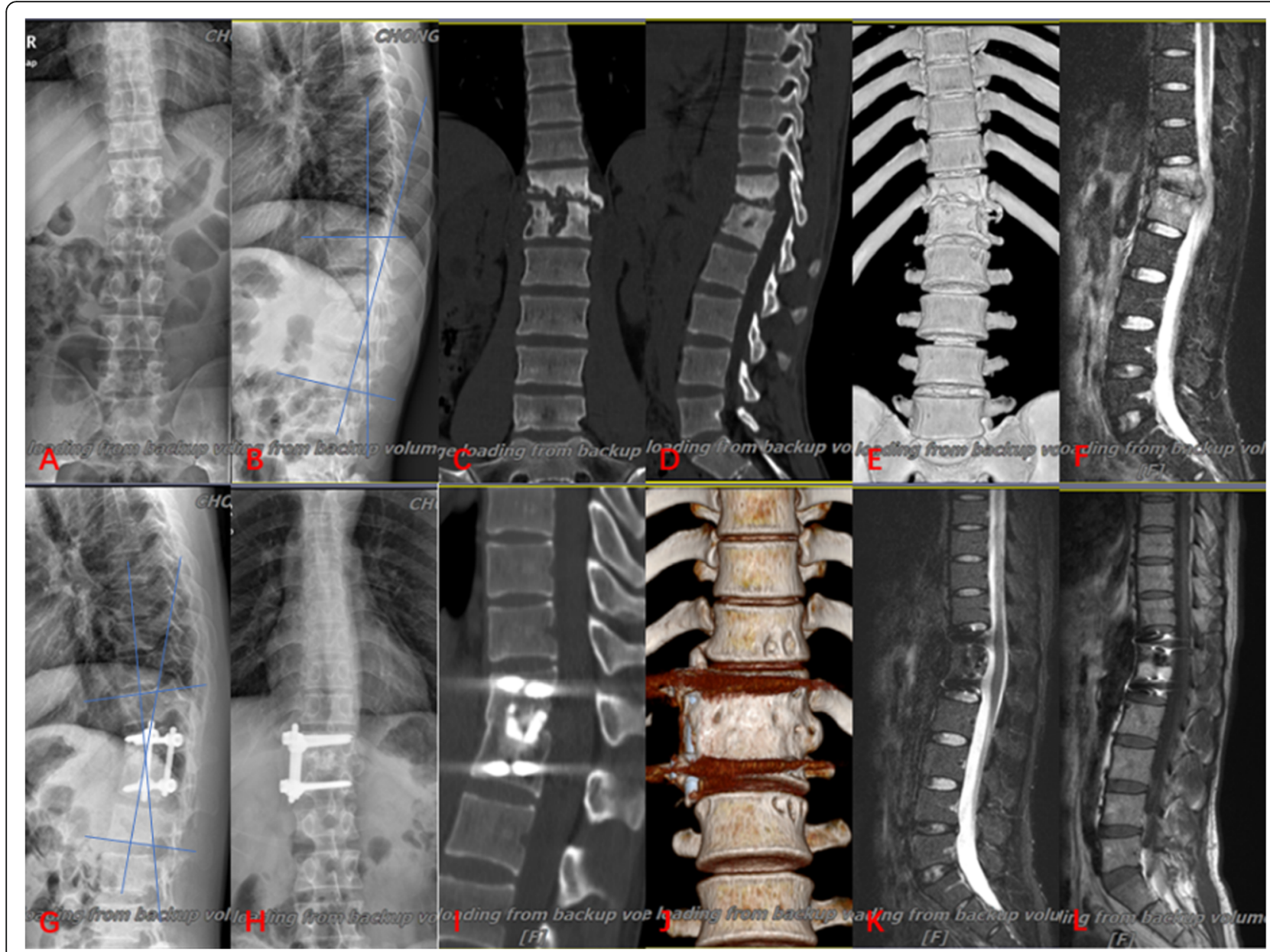

Fig. 2 The graph showed a case underwent anterior debridement, bone grafting and screw-rods internal fixation. 25-year-old man with thoracolumbar junction (T12-L1) TB (a, b) preoperative anteroposterior and lateral X-rays; $\mathbf{c}$, $\mathbf{d}$ preoperative computed tomography (CT); e preoperative 3D reconstruction of $C T ; \mathbf{f}$ preoperative MRI; $\mathbf{g}, \mathbf{h}$ ) X-ray at 18-month postoperative; $\mathbf{i} C T$ at 24-month postoperative; $\mathbf{j} 3 D$ reconstruction of $\mathrm{CT}$ at 24-month postoperative; $\mathbf{k}$, I MRI at 18-month postoperative

performed and the lamina and articular process were exposed. After the screws were placed in the right places, the transpedicular space was used to debride lesion tissues, such as abscesses, necrotic discs and endplates. Then, suitable size autograft iliac bone or titanium cage containing cancellous bone was inserted into intervertebral body. At last, installed the rods and rectified the kyphosis and/or scoliosis. Before the surgery of each group was over, isoniazid $(0.3 \mathrm{~g})$ and streptomycin $(1.0 \mathrm{~g})$ were administered locally, and tubes were placed routinely near the incision.

\section{Postoperative care}

Preventive antibiotic treatment was used within $48 \mathrm{~h}$ postoperatively. All cases were advised to use a bracing apparatus till bony fusion. Patients were administered oral HREZ chemotherapy for 6 months after the surgery, then received HRE chemotherapy for 9-12 months. When the drug sensitivity test indicated drug-resistant TB, sensitive drugs would be adjusted. Patients' ESR rates, liver and kidney function were re-examined regularly. Follow-up was performed at $1,3,6,12$ and 18 months, then conducted once each year.

\section{Statistical analysis}

Continuous data were expressed as $\overline{\mathrm{X}} \pm$ S.D. The LSD or Dunnett T3 test was used to evaluate differences in operation time, blood loss, kyphosis angle, ESR, VAS score. SPSS version 22 (SPSS, Inc., Chicago, USA) was used for statistical analysis. Values of $P$ less than 0.05 were considered to indicate significant differences.

\section{Results}

\section{General patient characteristics}

In group $\mathrm{A}$, the mean patient age, operation time, bleeding and duration of follow-up were $34.3 \pm 10.1$ years (range 18-62 years), 330.2 $\pm 45.4 \mathrm{~min}$ (range 200$400 \mathrm{~min}$ ), $744.0 \pm 193.8 \mathrm{ml}$ (range $500-1500 \mathrm{~mL}$ ) and 


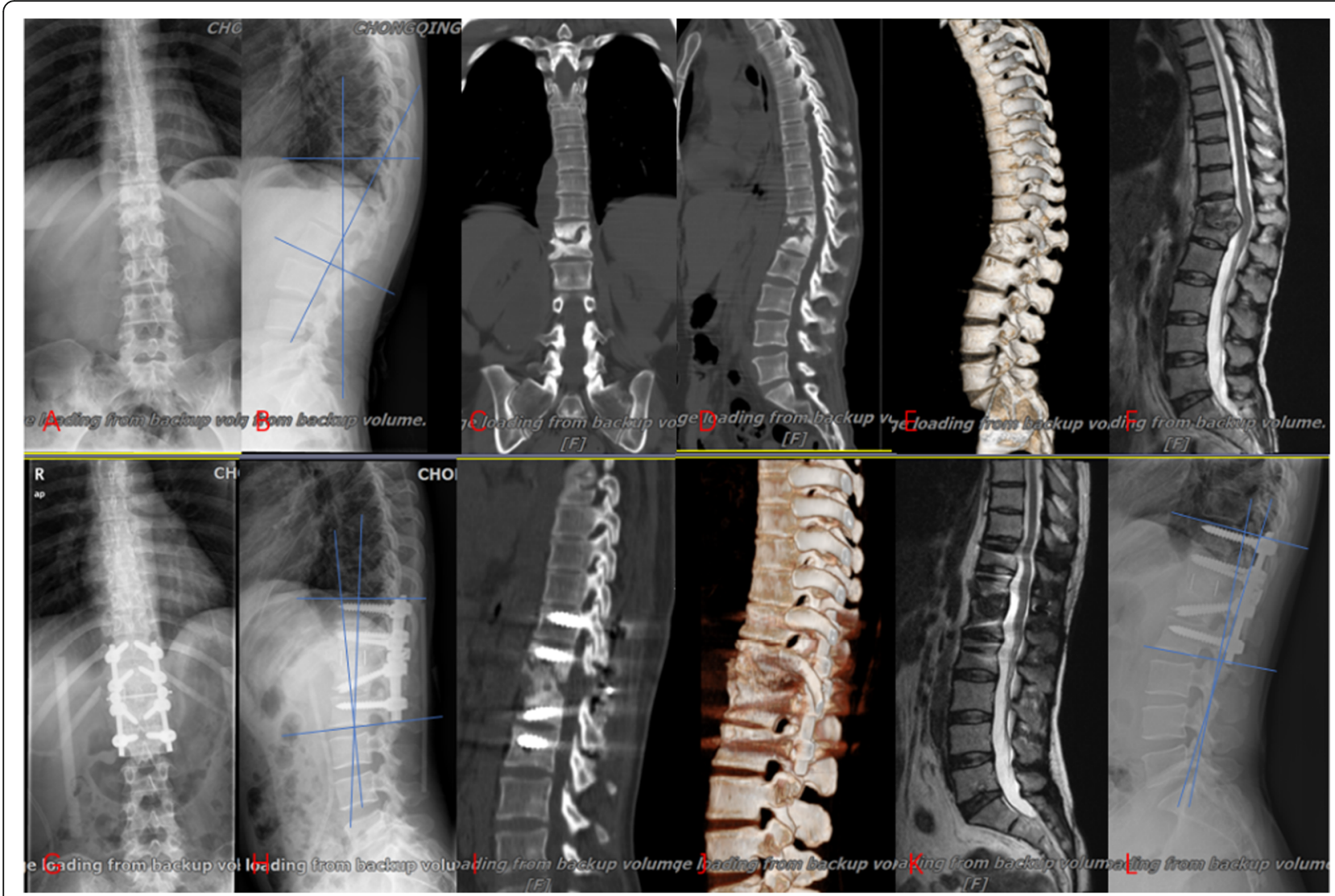

Fig. 3 The graph showed a case underwent one-stage anterior debridement, decompression, bone grafting and posterior instrumentation. 38year-old woman with thoracolumbar junction (T12-L1) TB (a, b) preoperative anteroposterior and lateral X-rays; $\mathbf{c}$, $\mathbf{d}$ preoperative CT; e preoperative 3D reconstruction of CT; $\mathbf{f}$ preoperative MRI; $\mathbf{g}, \mathbf{h}$ X-ray at 1-month postoperative; $\mathbf{i} C T$ at 6-month postoperative; $\mathbf{j} 3 D$ reconstruction of $C$ at 6 -month postoperative; $\mathbf{k}$ MRI at 13-month postoperative; I lateral X-rays at 56-month postoperative

$30.0 \pm 7.3$ months (range $24-50$ months), respectively. In group $B$, these were $34.4 \pm 10.4$ years (range $14-61$ years), $408.0 \pm 54.3 \mathrm{~min}$ (range 295-540 $\mathrm{min}$ ), $1134.6 \pm 328.2 \mathrm{ml}$ (range $400-2000 \mathrm{~mL}$ ) and $29.7 \pm 6.6$ months (range 24-50 months), respectively. In group $C$, they were $35.6 \pm 9.9$ years (range 14-62 years), 227.9 $\pm 58.5 \mathrm{~min}$ (range 123-600 $\mathrm{min}$ ), $349.8 \pm 289.4 \mathrm{ml}$ (range 200-2200 $\mathrm{mL}$ ) and $28.9 \pm 6.1$ months (range 24-52 months), respectively (Table 1).

\section{Laboratory evaluation}

The average preoperative ESR values were $34.7 \pm 27.0 \mathrm{~mm} /$ h (range 2-99 mm/h) in group A, $38.9 \pm 30.2 \mathrm{~mm} / \mathrm{h}$ (range 2 to $99 \mathrm{~mm} / \mathrm{h}$ ) in group $B$ and $36.3 \pm 25.0 \mathrm{~mm} / \mathrm{h}$ (range 2$99 \mathrm{~mm} / \mathrm{h}$ ) in group C. The postoperative ESR values turned to be normal in all cases at 3-month (Table 2).

\section{Function scores}

Neurologic function scores were tabulated in Table 3. All cases with neurological injury had different degrees of improvement postoperatively. The postoperative VAS of the three groups were decreased significantly at the last follow-up.

\section{Radiological evaluation}

The preoperative mean Cobb angle was $22.7 \pm 7.9^{\circ}$ in group A (Fig. 2), $18.1 \pm 6.8^{\circ}$ in group B (Fig. 3) and $20.8 \pm$ $8.3^{\circ}$ in group $\mathrm{C}$ (Fig. 4). The postoperative Cobb angle decreased significantly to $11.2 \pm 5.4^{\circ}$ in group $\mathrm{A}, 8.4 \pm 4.2^{\circ}$ in group $B$ and $8.7 \pm 3.8^{\circ}$ in group $C$. At the last follow-up, the kyphosis angle was $16.7 \pm 7.0^{\circ}, 10.1 \pm 4.4^{\circ}, 10.3 \pm 4.0^{\circ}$, in groups $\mathrm{A}, \mathrm{B}$ and $\mathrm{C}$ respectively. Compared with the preoperative Cobb angle, the postoperative and last follow-up Cobb angle in three groups had improved significantly (Table 2). By comparison of kyphosis angle loss, the results showed that the anterior-posterior and posterioronly procedure were superior to the anterior-only procedure in maintaining a corrective effect.

\section{Complications}

In group $\mathrm{A}$, there was 1 case of superficial wound infection, 1 case of cerebrospinal fluid leakage and 1 case of electrolyte imbalance. In group $B$, there were 1 case of 


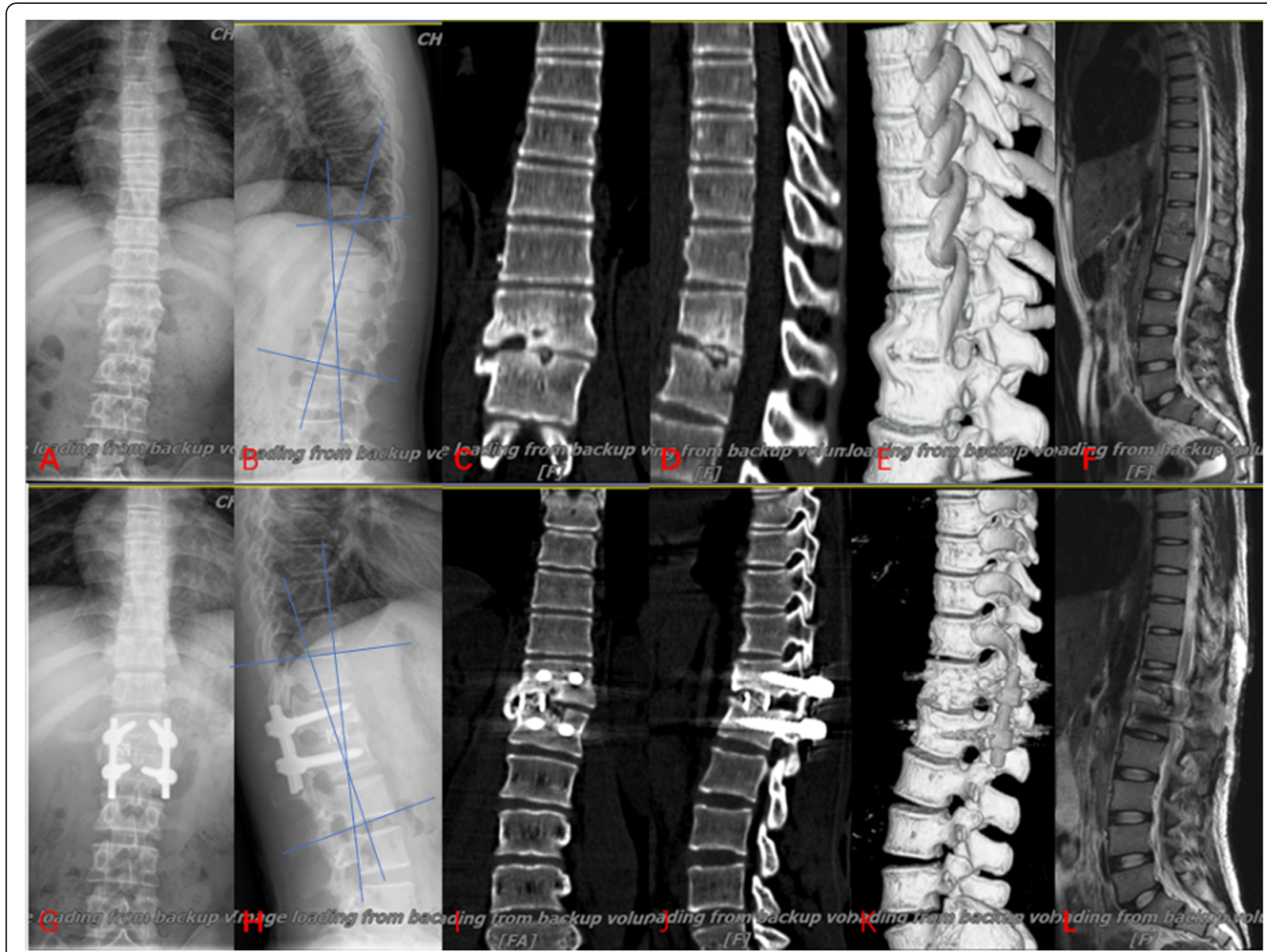

Fig. 4 The graph showed a case underwent posterior debridement, decompression, bone grafting and internal fixation instrumentation. 18-yearold man with thoracolumbar junction (T12-L1) TB $(\mathbf{a}, \mathbf{b})$ preoperative anteroposterior and lateral $\mathrm{X}$-rays; $\mathbf{c}, \mathbf{d}$ CT preoperative; $\mathbf{e} 3 \mathrm{D}$ reconstruction of $C T$ preoperative; $\mathbf{f}$ preoperative MRl; $\mathbf{g}, \mathbf{h}$ X-ray at 1-month postoperative; $\mathbf{i}, \mathbf{j} C T$ at 3-month postoperative; $\mathbf{k} 3 \mathrm{D}$ reconstruction of $C T$ at 12 month postoperative; I MRI at 12-month postoperative

pectoralgia, 1 case of urinary infection, 3 cases of cerebrospinal fluid leakage and 5 cases of electrolyte imbalance. In group $C$, there were 1 case of superficial wound infection, 5 cases of cerebrospinal fluid leakage, 1 case of electrolyte imbalance and 1 case of refractory intercostal neuralgia. All of these complications were treated successfully or relieved after symptomatic treatment (Table 4).

Table 4 Complications related to surgery

\begin{tabular}{llll}
\hline Complications & Group A & Group B & Group C \\
\hline Superficial wound infection & 1 & 0 & 1 \\
Cerebrospinal fluid leakage & 1 & 3 & 5 \\
Electrolyte imbalance & 0 & 5 & 1 \\
Urinary infection & 0 & 1 & 0 \\
Pectoralgia & 0 & 1 & 0 \\
Refractory intercostal neuralgia & 0 & 0 & 1 \\
\hline
\end{tabular}

\section{Discussion}

The thoracolumbar junction (T12-L1) is one of the main sites of metastatic musculoskeletal TB [6,7]. Although standard anti-TB chemotherapy is the fundamental method of treating spinal TB, suitable and timely surgical intervention for thoracolumbar spinal TB patients can improve spinal stability, decompress the spinal cord and prevent further development of spinal deformity and paralysis or death [17].

The thoracolumbar junction (T12-L1) is sandwiched between the peritoneum and pleura, and various surgical procedures have been used to access the area: anterioronly, anterior-posterior and posterior-only. The most common lesion area is major in anterior column of the spine involving only one motion segment [18]. Therefore, early scholars thought the anterior approach [9], which can allow direct access to the focus, complete debridement and valid decompression, would be the first choice for decompression and debridement in spinal TB. 
However, it can't prevent or correct kyphosis deformity to any appreciable extent [19]. In our study, the degree of kyphosis correction after surgery was similar in group A to that in groups $\mathrm{B}$ and $\mathrm{C}$, yet Cobb angle losses were larger in group $\mathrm{A}$ than in groups $\mathrm{B}$ and $\mathrm{C}$. Anterior instrumentation in spinal TB is becoming increasingly popular, because a bone grafting alone does not provide reliable stability. It can be very effective at correcting a deformity and maintaining the correction [20]. The use of biomaterials in lesion area is still in debate as it may undermine efforts to eradicate the infection [21]. However, some experts concluded that the usage of implants are safe because the M. tuberculosis are dividing too slowly to produce strong adhesion or thick biofilm in most cases [22].

The anterior-posterior procedure is an advanced surgical technique that not only achieves radical debridement of the abscess and adequate decompression of spinal cord, satisfactory correction of kyphosis deformity and long-term maintenance spinal stability, but also separates the debridement area from the instrumentation area that can decrease the spread of TB [20]. Disadvantages of the combined approach are longer operation time, higher complication rate, more blood loss and serious trauma. In our study, the operation time, bleeding, and complication rate were much greater with this approach than with other approaches.

Advantages of posterior-only procedure include less blood loss and shorter hospitalization and operative time. Other advantages are adequate decompression of spinal cord, correction of spinal deformity, reconstruction of spinal stability and improvement of patients' quality of life. Posterior-only procedure may be better in cases with less involved anterior column, which is almost always achieving spontaneous fusion [23, 24]. However, there is a possible risk of $\mathrm{TB}$ spreading to posterior healthy area, resulting in infection diffusion and/or fistulas [25]. In this research, the operation time, bleeding and complication rate were less than other groups, and group $\mathrm{C}$ achieved the same satisfactory kyphosis correction as group B during the follow-up period.

Our research has some limitations. First, this study was a retrospective rather than a prospective cohort study. Second, operations at each centre were performed by the respective senior medical teams of the 6 different centres, that may result in a certain degree of bias because of differences in their surgical proficiency.

\section{Conclusions}

This multicentre retrospective study showed that the posterior-only approach can be an effective treatment method for thoracolumbar junction (T12-L1) TB patients, with good neurologic recovery, avoidance of kyphosis progression and few complications.

\section{Abbreviations}

ASIA: American Spinal Injury Association; ESR: Erythrocyte sedimentation rate; HREZ: Isoniazid, rifampicin, ethambutol, pyrazinamide; TB: Tuberculosis; VAS: Visual analogue score

\section{Authors' contributions}

ZHZ and JZX designed this research. YC, JLT, LTL and ZLL participated in data collection. YPZ, PC and ZHZ participated in analysis and interpretation of data. YHZ, PC and GJW revised the draft. YPZ and PC were the main contributors in writing this manuscript. All authors read and approved the final manuscript.

\section{Funding}

This work was supported by the National Natural Science Foundation of China [grant number 81672193]. Jianzhong Xu, as the principal head of the fund, participated in the design of the research.

\section{Availability of data and materials}

The datasets used and analysed in this study are available from the corresponding author on reasonable request.

\section{Ethics approval and consent to participate}

This study was approved by the Ethics Committee of the First Affiliated Hospital of the Third Military Medical University. All participants have been informed and gave written consent prior to data collection.

\section{Consent for publication}

Written informed consent was obtained from the patients for publication of their clinical details and clinical images.

\section{Competing interests}

The authors declare that they have no competing interests.

\section{Author details}

${ }^{1}$ Department of Orthopaedics, Southwest Hospital, Third Military Medical University, Chongqing 400038, China. '2Department of Orthopaedics, Lanzhou Military Region General Hospital, Lanzhou, China. ${ }^{3}$ Department of Orthopaedics, Yulin People's Hospital, Yulin, China. ${ }^{4}$ Department of Orthopaedics, 8th Medical Centre of Chinese PLA General Hospital Tuberculosis Research Institute, Beijing, China. ${ }^{5}$ Department of Orthopaedics, Xi'an Jiaotong University Second Affiliated Hospital, Xi'an, China.

${ }^{6}$ Department of Orthopaedics, Affiliated Hospital of Southwest Medical University, Luzhou, China.

Received: 6 August 2019 Accepted: 10 October 2019

Published online: 09 November 2019

\section{References}

1. Ding P, Li X, Jia Z, Lu Z. Multidrug-resistant tuberculosis (MDR-TB) disease burden in China: a systematic review and spatio-temporal analysis. BMC Infect Dis. 2017;17(1):57 Available from: https://www.ncbi.nlm.nih.gov/ pubmed/28073344.

2. Zumla A, George A, Sharma V, Herbert N, Baroness Masham of I. WHO's 2013 global report on tuberculosis: successes, threats, and opportunities. Lancet. 2013;382(9907):1765-7 Available from: https://www.ncbi.nlm.nih. gov/pubmed/24269294.

3. Zhao $Y$, Xu S, Wang L, Chin DP, Wang S, Jiang G, Xia H, Zhou Y, Li Q, Qu X, Pang $Y$, Song $Y$, Zhao B, Zhang H, He G, Guo J, Wang Y. National survey of drug-resistant tuberculosis in China. N Engl J Med. 2012;366(23):2161-70 Available from: https://www.ncbi.nlm.nih.gov/pubmed/22670902.

4. Yao Y, Song W, Wang K, Ma B, Liu H, Zheng W, Tang Y, Zhou Y. Features of 921 patients with spinal tuberculosis: a 16-year investigation of a general Hospital in Southwest China. Orthopedics. 2017;40(6):e1017-23 Available from: https://www.ncbi.nlm.nih.gov/pubmed/29058758.

5. Boachie-Adjei O, Papadopoulos EC, Pellise F, Cunningham ME, Perez-Grueso FS, Gupta M, Lonner B, Paonessa K, King A, Sacramento C, Kim HJ, Mendelow M, Yazici M. Late treatment of tuberculosis-associated kyphosis: literature review and experience from a SRS-GOP site. Eur spine J. 2013; 22(Suppl 4):641-6 Available from: https://www.ncbi.n/m.nih.gov/ pubmed/22627623. 
6. Nagashima H, Yamane K, Nishi T, Nanjo Y, Teshima R. Recent trends in spinal infections: retrospective analysis of patients treated during the past 50 years. Int Orthop. 2010;34(3):395-9 Available from: https://www.ncbi.nlm. nih.gov/pubmed/19277654

7. Jain AK, Dhammi IK, Jain S, Kumar J. Simultaneously anterior decompression and posterior instrumentation by extrapleural retroperitoneal approach in thoracolumbar lesions. Indian J Orthop. 2010;44(4):409-16 Available from: https://www.ncbi.nlm.nih.gov/pubmed/20924482.

8. Zhang Z, Luo F, Zhou Q, Dai F, Sun D, Xu J. The outcomes of chemotherapy only treatment on mild spinal tuberculosis. J Orthop Surg Res. 2016;11(1):49 Available from: https://www.ncbi.nlm.nih.gov/pubmed/2 7177692 .

9. Tuli SM. Tuberculosis of the spine: a historical review. Clin Orthop Relat Res. 2007:460:29-38 Available from: https://www.ncbi.n/m.nih.gov/pubmed/174 83734.

10. Jain AK, Dhammi IK, Prashad B, Sinha S, Mishra P. Simultaneous anterior decompression and posterior instrumentation of the tuberculous spine using an anterolateral extrapleural approach. J Bone Joint Surg Br. 2008; 90(11):77-81 Available from: https://www.ncbi.nlm.nih.gov/pubmed/1 8978269.

11. Benli IT, Kaya A, Acaroglu E. Anterior instrumentation in tuberculous spondylitis: is it effective and safe? Clin Orthop Relat Res. 2007;460:108-16 Available from: https://www.ncbi.nlm.nih.gov/pubmed/17452918.

12. Soultanis K, Mantelos G, Pagiatakis A, Soucacos PN. Late infection in patients with scoliosis treated with spinal instrumentation. Clin Orthop Relat Res. 2003;(411):116-23 Available from: https://www.ncbi.nlm.nih.gov/pubmed/12 782866.

13. Cui $X$, Li LT, Ma YZ. Anterior and Posterior Instrumentation with Different Debridement and Grafting Procedures for Multi-Level Contiguous Thoracic Spinal Tuberculosis. Orthop Surg. 2016;8(4):454-61.

14. Zhang $H Q$, Guo CF, Xiao XG, Long WR, Deng ZS, Chen J. One-stage surgical management for multilevel tuberculous spondylitis of the upper thoracic region by anterior decompression, strut autografting, posterior instrumentation, and fusion. J Spinal Disord Tech. 2007;20(4):263-7 Available from: https://www.ncbi.nlm.nih.gov/pubmed/17538348.

15. D'Souza AR, Mohapatra B, Bansal ML, Das K. Role of posterior stabilization and Transpedicular decompression in the treatment of thoracic and thoracolumbar TB: a retrospective evaluation. Clin Spine Surg. 2017;30(10): E1426-33 Available from: https://www.ncbi.nlm.nih.gov/pubmed/28169940.

16. Hu X, Zhang H, Yin $X$, Chen $Y, Y u H$, Zhou Z. One-stage posterior focus debridement, fusion, and instrumentation in the surgical treatment of lumbar spinal tuberculosis with kyphosis in children. Childs Nerv Syst. 2016; 32(3):535-9 Available from: https://www.ncbi.nlm.nih.gov/pubmed/26527476

17. He Z, Tang K, Gui F, Zhang Y, Zhong W, Quan Z. Comparative analysis of the efficacy of a transverse process bone graft with other bone grafts in the treatment of single- segment thoracic spinal tuberculosis. J Orthop Surg Res. 2019;9:1-8.

18. Varatharajah S, Charles YP, Buy X, Walter A, Steib JP. Update on the surgical management of Pott's disease. Orthopaedics and Traumatology: Surgery and Research; 2014.

19. Lu G, Wang B, Li J, Liu W, Cheng I. Anterior debridement and reconstruction via thoracoscopy-assisted mini-open approach for the treatment of thoracic spinal tuberculosis: minimum 5-year follow-up. Eur Spine J. 2012;21(3):463-9 Available from: https://www.ncbi.nlm.nih.gov/pubmed/21997276.

20. Chen WJ, Wu CC, Jung CH, Chen LH, Niu CC, Lai PL. Combined anterior and posterior surgeries in the treatment of spinal tuberculous spondylitis. Clin Orthop Relat Res. 2002;(398):50-9 Available from: https://www.ncbi.nlm.nih. gov/pubmed/11964631.

21. Faraj $A A$, Webb JK. Spinal instrumentation for primary pyogenic infection report of 31 patients. Acta Orthop Belg. 2000;66(3):242-7 Available from: https://www.ncbi.nlm.nih.gov/pubmed/11033912.

22. Singh K, Vaccaro AR, Kim J, Lorenz EP, Lim TH, An HS. Biomechanical comparison of cervical spine reconstructive techniques after a multilevel corpectomy of the cervical spine. Spine (Phila pa 1976). 2003;28(20):2352-8 discussion 2358. Available from: https://www.ncbi.nlm.nih.gov/ pubmed/14560082.

23. Hee HT, Majd ME, Holt RT, Pienkowski D. Better treatment of vertebral osteomyelitis using posterior stabilization and titanium mesh cages. J Spina Disord Tech. 2002;15(2):149-56 discussion 156. Available from: https://www. ncbi.nlm.nih.gov/pubmed/11927825.
24. Qian J, Rijiepu A, Zhu B, Tian D, Chen L, Jing J. Outcomes of radical debridement versus no debridement for the treatment of thoracic and lumbar spinal tuberculosis. Int Orthop. 2016;40(10):2089.

25. Zhang H, Sheng B, Tang M, Guo C, Liu S, Huang S, Gao Q, Liu J, Wu J. Onestage surgical treatment for upper thoracic spinal tuberculosis by internal fixation, debridement, and combined interbody and posterior fusion via posterior-only approach. Eur Spine J. 2013;22(3):616-23.

\section{Publisher's Note}

Springer Nature remains neutral with regard to jurisdictional claims in published maps and institutional affiliations.

\section{Ready to submit your research? Choose BMC and benefit from:}

- fast, convenient online submission

- thorough peer review by experienced researchers in your field

- rapid publication on acceptance

- support for research data, including large and complex data types

- gold Open Access which fosters wider collaboration and increased citations

- maximum visibility for your research: over $100 \mathrm{M}$ website views per year

At $\mathrm{BMC}$, research is always in progress.

Learn more biomedcentral.com/submissions 